\title{
Socioeconomic Impact of Small Water Impounding Projects in Quirino Province, Philippines
}

\author{
Rey C. Naval \\ College of Agriculture, Forestry and Engineering, Quirino State University, Diffun, Philippines \\ Email: reyn.qsu@gmail.com
}

Received 14 May 2016; accepted 18 June 2016; published 21 June 2016

Copyright (C) 2016 by author and Scientific Research Publishing Inc.

This work is licensed under the Creative Commons Attribution International License (CC BY).

http://creativecommons.org/licenses/by/4.0/

(c) (i) Open Access

\section{Abstract}

The study was conducted to determine the socioeconomic impact two (2) Small Water Impounding Projects (SWIPs) namely Burgos SWIP in Cabarroguis and Divisoria Norte SWIP in Maddela, both in the Province of Quirino, Philippines. The study made use of structured questionnaire to gather the socio-demographic profile and determined the socioeconomic impact of the SWIPs to the farmer-beneficiaries. Most of the farmer-beneficiaries of Burgos and Divisoria Norte SWIPs are male, 40 - 59 years old, married, have below four household members, Roman Catholic, high school graduates and some are members of cooperatives. They are rice farmers, and have attended one to two training courses related to farming and own a 1.00 to 1.99 hectares farm. "Utilization of water in the reservoir for other purposes like wallowing pool for carabaos" and "integration of fish production and livestock raising" were the identified benefits at the farmer's level while "introduction of new techniques in farming by the Local Government Units," "availability of cheap fish and additional income as a result of integration of fish production" and "construction of better roads" were the identified benefits at the community level. The SWIPs have positive impact as confirmed by the increase in the annual mean yield and in the annual gross income of the farmerbeneficiaries. It contributed a significant increase of 2.14 tons/year in the mean yield generating an additional income of PhP 32,113.64 for Burgos SWIP. On the other hand, it contributed a significant increase of 2.08 tons/year giving an additional income of $\mathrm{PhP}$ 31,313.60 for Divisoria Norte farmer-beneficiaries. The result of this study will provide strategic information to policy makers of agricultural and irrigation agencies on the existing weaknesses of irrigation systems in the country and determine in a more quantifiable terms level of potential improvement and investment targets.

\section{Keywords}

Small Water Impounding Project, Socioeconomic Impact, Quirino Province 


\section{Introduction}

The scientific community widely agrees that climate change is already a reality. It is undoubtedly the biggest challenge confronting the Philippines today and the vulnerability of water resources to this phenomenon is a reality that can no longer be ignored [1]. The effects of climate change on the country's agriculture vary by region and are expected to bring adverse changes in temperature and precipitation with particular on floods and droughts occurrences. Drought effects include crop losses due to insufficient soil moisture. The increasing food demand and decreasing water availability suggest that the agricultural sector has to produce more food with less water.

The growing concerns on water scarcity especially in the agricultural sector pose a major challenge among decision makers to put more focus on making this resource available. In the Philippines, the average annual rainfall is $2400 \mathrm{~mm}$ which is adequate to meet the annual water demand for crop production. However, rainfall is unevenly distributed throughout the year in most parts of the country resulting to excessive runoff and flooding during rainy months and water deficits during the dry months. Since the available amount of water is limited, scarce and not spatially distributed in relation to the population needs, proper management of water resources is essential to satisfy the current demands as well as to maintain sustainability [2].

Storage is the key constraint to providing water in dry periods, when demands are highest and supplies lowest. Dams, groundwater aquifer and small-scale water harvesting provide water storage. Dams have received the greatest investment, especially in the last 50 years. However, dams have become increasingly expensive in financial, environmental, and political terms. As the best sites are used up, the environmental cost of submerging forests and wildlife and the loss of land and livelihoods for those who are flooded out have given rise in organized political opposition. As the limitations of larger-scale storage in reservoir have become apparent, there have a renewed interest in smaller-scale water harvesting. Although small, water harvesting structures can collect considerable volumes of water for storage above ground or in soil profiles [3].

On the other hand, it was found out that the uptake of appropriate smallholder irrigation technology was variable and that there is a continuing need to raise awareness and disseminate information about irrigation about rural people [4].

The Department of Agriculture (DA) identified the development of Small Water Impounding Project (SWIP) as priority because it supports the irrigation and inland fishery programs of the government. The strengthening of this program was expected to provide optimum utilization of lakes and reservoirs in the upland areas for agricultural production. SWIPs are usually implemented in partnership with Local Government Units (LGUs) that have technical capability to implement such types of project. In most cases, LGUs provide counterpart funds, a scheme in which both the national and local governments share accountability to the project.

SWIP is water harvesting method and storage structure consisting of an earth embankment, spillway, outlet works and canal facilities. It is designed for soil and water conservation and flood control by holding as much water as possible during the rainy season for productive use during dry season. It provides supplemental irrigation water for intensified crop production which may substantially increase farmers' income. In addition, SWIP also contributes to the water requirements of livestock production, aquaculture, power generation, and recreation. SWIPs have proven their impact in regions where there is pronounced wet and dry seasons like Northern Philippines. During the wet season, excess water is impounded by SWIPs and then used during the dry season. The Bureau of Soils and Water Management (BSWM) spend almost PhP 3 billion to establish the 2060 SWIPs nationwide from 1974 to 2010, irrigating an approximate area of 84,168 hectares and benefiting 64,266 farmers [5]. Because of the enormous contribution of SWIPs to agricultural production, there is a need to assess these development projects to determine impact for sustainability and basis for policy formulation.

This study assessed the socioeconomic impact of Burgos and Divisoria Norte SWIPs in the Province of Quirino. It also determined the socio-demographic profile of the farmer-beneficiaries. It also assessed the change in yield and gross income as results of putting up the SWIPs.

\section{Materials and Methods}

From the existing list in the region, Burgos and Divisoria Norte SWIPs were selected considering their difference in the length of operation for comparison of SWIPs constructed over 15 years and currently operated. Burgos and Divisoria SWIPs were constructed in 1998 and 2007, respectively [6]. The relative location of SWIPs in the province is shown in Figure 1.

Burgos SWIP was completed in 1998 with a construction cost of PhP 1.22 M and designed to irrigate a service 


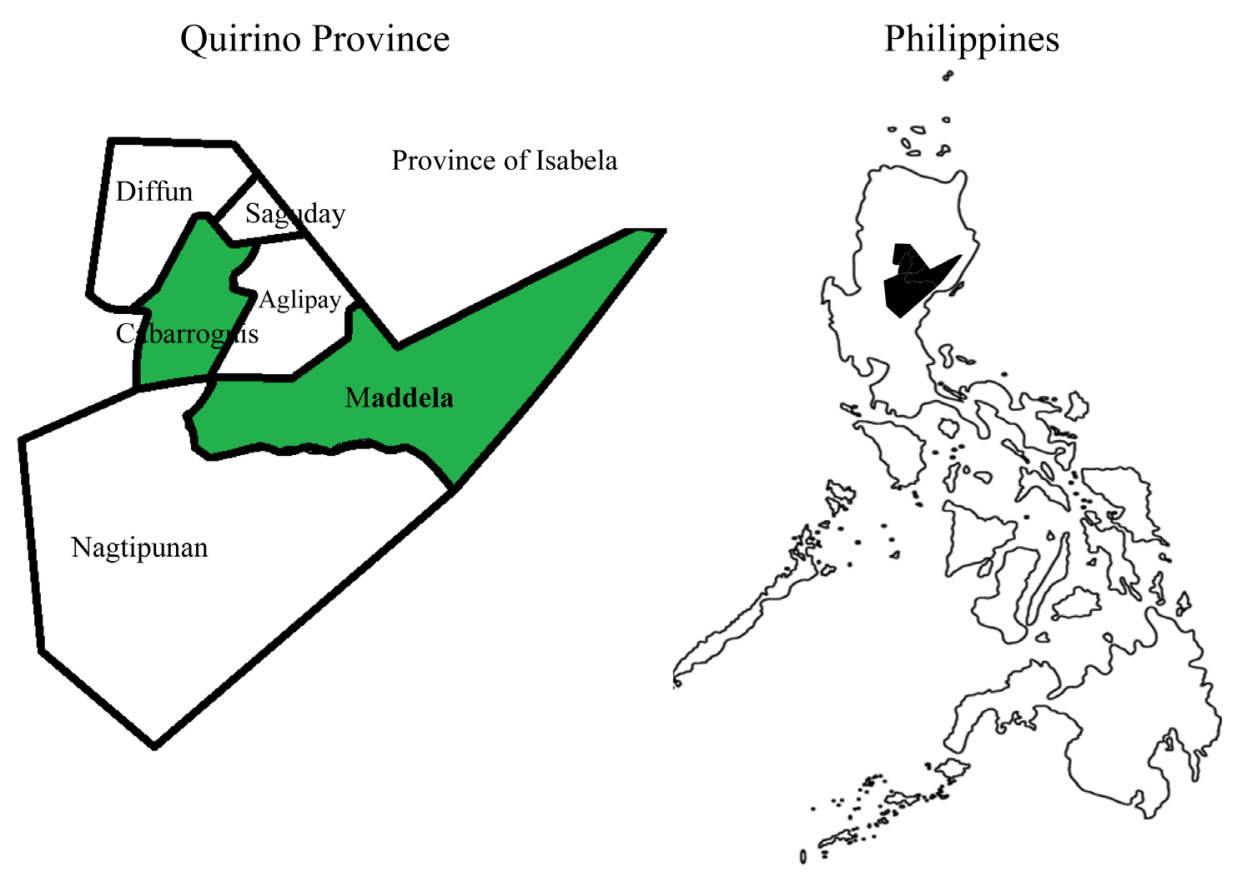

Figure 1. Location of Burgos and Divisoria Norte SWIP.

area of 30 hectares with 23 farmer-beneficiaries. It is situated $16^{\circ} 28^{\prime} 15^{\prime \prime}$ North latitude and $121^{\circ} 30^{\prime} 27^{\prime \prime}$ East longitude. The reservoir has total area of 1.10 hectares with an average depth of 3.28 meters. The volume of impounded water is approximately 36,080 cubic meters. The embankment is 48 meters long, 5 meters wide and about 156 meters above mean sea level.

The Burgos SWIP watershed is located between 16 $29^{\prime} 50^{\prime \prime}$ and $16^{\circ} 37^{\prime} 47^{\prime \prime}$ North latitudes and $121^{\circ} 29^{\prime} 56^{\prime \prime}$ and $121^{\circ} 32^{\prime} 44^{\prime \prime}$ East longitudes. It has a total area of 45.25 hectares.

The Burgos SWIP service area is located between $16^{\circ} 30^{\prime} 29^{\prime \prime}$ and $16^{\circ} 36^{\prime} 25^{\prime \prime}$ North latitudes and $121^{\circ} 33^{\prime} 29^{\prime \prime}$ and $121^{\circ} 37^{\prime} 14^{\prime \prime}$ East longitudes.

Divisoria Norte SWIP, on the other hand, was completed in 2007 with a construction cost of PhP 800,000.00 and designed to irrigate a service area of 46 hectares with 35 farmer-beneficiaries. It is situated $16^{\circ} 24^{\prime} 24^{\prime \prime}$ North latitude and $121^{\circ} 43^{\prime} 30$ " East longitude. The reservoir has total area of 4.90 hectares with an average depth of 3.67 meters. The volume of impounded water is approximately 179,830 cubic meters. The embankment is 70 meters long and 5 meters wide.

Its watershed is located between $16^{\circ} 24^{\prime} 05^{\prime \prime}$ and $16^{\circ} 24^{\prime} 32^{\prime \prime}$ North latitudes and $121^{\circ} 43^{\prime} 23^{\prime \prime}$ and $121^{\circ} 44^{\prime} 01^{\prime \prime}$ East longitudes. The topography of the area ranges from flat to undulating valleys and steep mountains.

The Divisoria Norte SWIP service area is located between $16^{\circ} 24^{\prime} 21^{\prime \prime}$ and $16^{\circ} 24^{\prime} 34^{\prime \prime}$ North latitudes and $121^{\circ} 43^{\prime} 35^{\prime \prime}$ and $121^{\circ} 43^{\prime} 49^{\prime \prime}$ East longitudes. The service area is about 40 hectares which predominantly planted with rice.

The needed data was gathered through an actual interview of farmer-beneficiaries using a structured questionnaire [7].

Frequency counts and percentages were used to describe the socio-demographic profile of the farmer-beneficiaries. Mean was used to describe the yield and income of the farmer-beneficiaries before and after the SWIPs while t-test was used to compare and find out the existence of significant difference on the yield and income of the farmer-beneficiaries before and after the SWIPs [8].

\section{Results and Discussion}

\subsection{Socio-Demographic Profile}

Based on the results presented in Table 1, it implies that farm work is dominated by male and majority of the agricultural workers are male. 
Table 1. Frequency and percent distribution of respondents by profile.

\begin{tabular}{|c|c|c|c|}
\hline Profile & Specifics & Frequency & Percent \\
\hline \multirow[t]{2}{*}{ Sex } & Male & 43 & 87.76 \\
\hline & Female & 6 & 12.24 \\
\hline \multirow[t]{2}{*}{ Age } & $20-39$ & 10 & 20.41 \\
\hline & $40-59$ & 26 & 53.06 \\
\hline Mean $=51.57$ years old & $60-79$ & 13 & 26.53 \\
\hline \multirow[t]{3}{*}{ Civil status } & Single & 2 & 4.08 \\
\hline & Married & 46 & 93.88 \\
\hline & Widow & 1 & 2.04 \\
\hline \multirow[t]{3}{*}{ Number of household members } & 4 and below & 33 & 67.35 \\
\hline & $5-7$ & 13 & 26.53 \\
\hline & 8 and above & 3 & 6.12 \\
\hline \multirow[t]{4}{*}{ Religion } & Roman Catholic & 40 & 81.63 \\
\hline & Evangelist & 5 & 10.20 \\
\hline & Church of Christ & 2 & 4.08 \\
\hline & Espiritista & 2 & 4.08 \\
\hline \multirow[t]{5}{*}{ Educational attainment } & Elementary level & 6 & 12.24 \\
\hline & Elementary graduate & 9 & 18.37 \\
\hline & High school graduate & 21 & 42.86 \\
\hline & College level & 7 & 14.29 \\
\hline & College graduate & 6 & 12.24 \\
\hline \multirow[t]{4}{*}{ Organizational membership } & Cooperatives & 12 & 24.49 \\
\hline & Fisher folks & 3 & 6.12 \\
\hline & Religious & 1 & 2.04 \\
\hline & None & 33 & 67.35 \\
\hline \multirow[t]{4}{*}{ Major source of income } & Rice farming & 44 & 89.80 \\
\hline & Citrus production & 1 & 2.04 \\
\hline & Salary of spouse & 1 & 2.04 \\
\hline & Own salary & 3 & 6.12 \\
\hline \multirow[t]{3}{*}{ Number of training attended } & $1-2$ & 40 & 81.63 \\
\hline & $3-4$ & 8 & 16.33 \\
\hline & $5-6$ & 1 & 2.04 \\
\hline \multirow[t]{3}{*}{ Farm area } & Less than 1 hectare & 18 & 36.73 \\
\hline & 1 to 1.99 hectares & 26 & 53.06 \\
\hline & More than 2 hectares & 5 & 10.20 \\
\hline \multirow[t]{3}{*}{ Tenurial status } & Owner & 38 & 77.55 \\
\hline & Rented & 2 & 4.08 \\
\hline & Tenant & 9 & 18.37 \\
\hline
\end{tabular}

$\mathrm{n}=49$. 
The result also shows that there is a wide variation on the age of the farmer-beneficiaries. The mean age of 51.57 indicates that most of them are in their prime age and are generally in the peak of physical capability to perform development and other socioeconomic activities.

The data also shows that majority of the farmer-beneficiaries are composed of four or less household members with a mean household size of four and a standard deviation of 3.57. The aforementioned finding is consistent with the average household of the province, which is four [9].

The result on the major source of income is in consonance with the classification of the Province of Quirino as having an agriculture-based economy and that farming is the major source of livelihood [10].

The data on tenurial status reveals that the farmer-beneficiaries of the Burgos and Divisoria Norte SWIPs own and operate their farms with only some who are tenants and renting. From the data, it appears that land ownership is not a problem in the study area.

\subsection{Socioeconomic Impact of SWIP}

Of the SWIPs' benefits at the farmer level (Table 2), majority (71.43\%) of the farmer-beneficiaries identified "utilization of water in the reservoir for other purposes like "wallowing pool for carabaos" and "integration of fish production and livestock raising" with $36.73 \%$.

Among the identified benefits derived from the SWIPs at the community level were" introduction of new techniques in farming by the LGUs" with 59.18\%, "availability of cheap fish and additional income as a result of integration of fish production" with $36.73 \%$ and "construction of better roads" with $18.37 \%$.

\subsection{Yield and Gross Income}

Based from Table 3, result of the t-test reveals that there is a 2.14 tons/year significant increase in the mean annual yield after the Burgos SWIP existed. On the other hand, there is a 2.08 significant increase in the mean annual yield of the farmers after the Divisoria Norte SWIP existed.

This implies that Burgos and Divisoria Norte SWIPs have positive impact on the yield of the farmer-beneficiaries. This supports the findings in other locations [8] [10] [11].

In terms of the mean annual gross income of the farmers, the results imply that Burgos and Divisoria Norte SWIPs are beneficial to the farmer-beneficiaries. The results also coincide with the findings of [8] [10] [11].

Table 2. Socioeconomic impact of SWIP.

\begin{tabular}{lcc}
\hline \multicolumn{1}{c}{ Socioeconomic impact } & Frequency n $=49$ & Percent \\
\hline Farmer level & 18 & 36.73 \\
Integration of fish production and livestock raising & 35 & 71.43 \\
Utilization of water in the reservoir for other purposes & 18 & 36.73 \\
Community level & 9 & 18.37 \\
Availability of cheap fish for the community due to integration of fish production & 29 & 59.18 \\
Construction of better roads & & \\
Introduction of new techniques in farming by DA, LGU and other agencies &
\end{tabular}

Table 3. t-test on the mean annual yield of farmer-beneficiaries before and after SWIPs.

\begin{tabular}{|c|c|c|c|c|}
\hline Condition & $\begin{array}{l}\text { Mean annual yield } \\
\text { (tons/year) }\end{array}$ & t-computed & Probability value & Result \\
\hline Before Burgos SWIP & 8.33 & \multirow[b]{2}{*}{$3.386^{* *}$} & \multirow[b]{2}{*}{0.003} & \multirow[b]{2}{*}{ Reject Ho } \\
\hline After Burgos SWIP & 10.47 & & & \\
\hline Before Divisoria SWIP & 6.65 & \multirow{2}{*}{$2.422^{*}$} & \multirow{2}{*}{0.032} & \multirow{2}{*}{ Reject Ho } \\
\hline After Divisoria SWIP & 8.73 & & & \\
\hline
\end{tabular}

Probability value of .05 and below are significant and above 0.05 are not significant. 


\section{Conclusions}

Burgos and Divisoria SWIPs have wide watershed area with relatively good vegetation. Thus, the water production potential of the SWIPs is sustainable. However, the farmer-beneficiaries have no Irrigators' Association and they lack training and capacity building in the operation and maintenance of the system.

Farmer-beneficiaries identified only few socioeconomic benefits of SWIP both at farmer's and community levels. The SWIPs have positive impact as evidenced by the significant increase in the mean annual yield and net income of the farmer-beneficiaries. For Burgos SWIP, their mean yield is significantly increased by 2.14 tons/year while their gross annual income is increased by PhP 32,113.64 while for Divisoria SWIP, their mean annual yield and gross annual income is significantly increased by 2.08 tons/year and PhP 31,313.60, respectively.

\section{Acknowledgements}

Special thanks to Quirino State University headed by Dr. Samuel O. Benigno, University President, Dr. Fredisminda M. Dolojan, Director for Research and For. Elizabeth T. Carig, Program Chair, Forestry; to the Isabela State University Faculty and Staff, Dr. Orlando F. Balderama, Dean, College of Engineering, Engr. Lanie A. Alejandro, Program Chair, BSAE and Elmer Rosete, Research Staff; and to the Nueva Vizcaya State University, Dr. Edwin P. Ramos, Vice President for Administration, Dr. Jessie Pascual P. Bitog Dr. Arvin P. Vallesteros, Dr. Yolina T. Castaneto and Dr. Ramil S. Rodriguez, Faculty Members.

\section{References}

[1] Philippine Rainfed RD \& E Program (PhiRARDEP) (2012) Department of Agriculture, Bureau of Agricultural Research Leaflets, Leaflets.

[2] Contreras, S.M. (2006) Small Water Impounding Project: A Small Eco-Efficient Infrastructure in the Upland Communities of the Philippines. Proceedings on Sustainable Infrastructure in Asia: A Seoul Initiative Policy Forum on Sustainable Infrastructure, Seoul.

[3] Meizen, R.S. (2001) Overcoming Water Scarcity and Quality Constraints. Focus 9, 2020 Vision. International Food Policy Research Institute, Washington DC.

[4] International Program for Technology and Research in Irrigation and Drainage (IPTRID) (2007) Water Harvesting Technologies. Food and Agriculture Organization of the United Nations, Rome.

[5] Bureau of Soils and Water Management (2011) BSWM Helps Sustainable Agriculture. Greenfields Magazine, Philippines.

[6] Department of Agriculture (2011) Inventory of Small Water Impounding Projects in Region 02, Philippines.

[7] Monsalud, F.C., Montesur, J.G. and Limosinero, R.L. (2003) Coping Strategies against El Niño: The Case of Selected Communities in Talugtog, Nueva Ecija, Philippines. Proceedings of a Joint Workshop on Coping against El Niño for Stabilizing Rainfed Agriculture: Lesson from Asia and the Pacific, CGPRT Center, Indonesia.

[8] Bartolome, E.R. (2004) Performance Evaluation and Impact Assessment of a Small Water Impounding Project in San Marcos, Cabarroguis, Quirino. Unpublished Thesis, Isabela State University, Echague.

[9] National Statistics Office (NSO) (2013) Quirino-Quick Stat.

[10] Quirino Forestry Master Plan (QFMP) (2008)

[11] Aves, R.O. (2006) Impact Assessment of Small Water Impounding Project in Bayombong, Nueva Vizcaya. Unpublished Thesis, Isabela State University, Echague. 


\section{Submit or recommend next manuscript to SCIRP and we will provide best service for you:}

Accepting pre-submission inquiries through Email, Facebook, Linkedin, Twitter, etc A wide selection of journals (inclusive of 9 subjects, more than 200 journals)

Providing a 24-hour high-quality service

User-friendly online submission system

Fair and swift peer-review system

Efficient typesetting and proofreading procedure

Display of the result of downloads and visits, as well as the number of cited articles

Maximum dissemination of your research work

Submit your manuscript at: http://papersubmission.scirp.org/ 